\title{
Revisiting Curriculum Potential
}

\author{
(Final version: August 16, 2010) \\ Zongyi DENG \\ National Institute of Education \\ Nanyang Technological University \\ 1 Nanyang Walk, Singapore 637616 \\ E-mail: zongyi.deng@nie.edu.sg
}

\begin{abstract}
This paper analyzes the notion of curriculum potential by revisiting the ideas of Miriam Ben-Peretz and Joseph Schwab. Invoking the German Didaktik tradition and by way of a curriculum making framework, the paper argues that interpreting curriculum materials for curriculum potential requires a careful analysis and unpacking of the meanings and significance of the content contained in materials. This analysis and unpacking need to be informed by an understanding of the "curriculum" embodied in materials. More specifically, it needs to take account of its theory of content - a special way of selecting, arranging, and framing content for educational and pedagogical purposes.
\end{abstract}

Manuscript to be published in Curriculum Inquiry 


\section{Introduction}

Curriculum materials (syllabuses, textbooks, or teacher guides) are important resources that carry "capacity" for classroom teaching (Cohen, Raudenbush, \& Ball, 2003). They are tools used by teachers and agents of instructional reform (Ball \& Cohen, 1996; Cohen \& Ball, 1990a, 1990b). Embodied in curriculum materials is a curriculum (a school subject, program or course of study) in which the content is selected, organized and transformed for social, cultural, educational, curricular and pedagogical purposes (Deng, 2009; Deng \& Luke, 2008). Yet what curriculum potential a material has depends on how a teacher uses the material which, in turn, depends on how he or she interprets what is contained in the material in a classroom context.

Over the last two decades teachers' use of curriculum materials has received significant attention among researchers. A body of literature has been accumulated that explores how teachers interpret and enact curriculum materials in classrooms in the light of their beliefs, knowledge, narratives or experiences (e.g., Brown \& Edelson, 2003; Collopy, 2003; Davis, 2006; Freeman \& Porter, 1989; Nicol \& Crespo, 2006; Schneider, Krajcik, \& Blumenfeld, 2005; Sherin \& Drake, 2009; Shkedi, 1998, 2009; Remillard, 1999, 2000; 2005). Researchers tend to foreground the agency of a classroom teacher rather than what is contained in curriculum materials. As a result, this body of literature tells us very little about what is involved in interpreting the curriculum embodied in materials for curriculum potential.

A preoccupation with the teacher's agency rather than with the curriculum is also evident in the model of pedagogical reasoning articulated by Shulman and associates when advancing their conceptualization of teachers' specialized subject matter 
knowledge - in terms of content knowledge, pedagogical content knowledge (PCK), and curricular knowledge (see Shulman, 1986, 1987; Wilson, Shulman, \& Richert, 1987). The teacher is expected to critically interpret curriculum materials in terms of his or her content knowledge - including knowledge of the substantive and syntactic structures of the academic discipline, terms borrowed from Schwab (1964)—when engaged in lesson planning. By means of PCK, the teacher is expected to transform his or her understanding of the content of the academic discipline into "forms that are pedagogically powerful and yet adaptive to the variations in ability and background presented by the student" (Shulman, 1987, p. 15). In other words, the teacher's content knowledge and PCK allows him or her "eventually to lift the curriculum away from texts and materials to give it independent existence" (Doyle, 1992a, p. 499). Curriculum materials thus have only symbolic meanings. As a result, Shulman and associates do not have much to say about how a teacher interprets and discloses curriculum potential in view of the curriculum embodied in materials.

This article makes a case for interpreting curriculum materials for curriculum potential by way of analyzing and unpacking the meaning and significance of content contained in materials. It argues that this analysis and unpacking needs to be informed by an understanding of the curriculum embodied in materials. More specifically, it needs to take account of its theory of content-that is, a particular way of selecting, arranging, and framing or translating content for educational and pedagogical purposes. This theory of content, which stems from the work of constructing curriculum materials by curriculum developers, "imbues" materials with (intended) curriculum potential. 
The term curriculum potential was arguably first introduced by Joseph Schwab (1973) and later on further developed by Miriam Ben-Peretz (1975, 1990). The article will start with analyzing the ideas of Ben-Peretz and Schwab. It will next move to discuss what it means to analyze curriculum content for educational potential in the German Didaktik tradition — a tradition that has developed a framework for analyzing curriculum potential in a classroom context, yet is largely unknown in the English speaking countries (Hopmann, 2007). Note that "curriculum potential" and "educational potential" are used interchangeably throughout this article. Afterward, the article will discuss what an analysis of curriculum content for potential entails, by way of a curriculum making framework informed by the writings of Doyle, Goodlad, and Westbury. An illustration will be provided through a discussion of what is involved in interpreting the content of liberal studies — a core school subject in the new senior secondary curriculum in Hong Kong. The article will conclude by discussing the significance and implications of the argument.

\section{Miriam Ben-Peretz}

Though implementers and evaluators tend to view any curriculum as the embodiment of its developers' intentions, curriculum materials may be viewed as expressing more than the fixed intentions of their developers. Once materials have left the originators' hands they may be interpreted and used in many ways. Curriculum may be seen as the embodiment of a potential, independent of its developers' intentions, that can be discovered and revealed by careful analysis. In such a view different interpretations of curricula would be made available to teachers for implementation as well as to evaluators for the judging of programs. (Ben-Peretz, 1975, p. 151)

Ben-Peretz's notion of curriculum potential was developed to call attention to the diverse

possible uses of curriculum materials by teachers in classroom contexts. She questioned 
the notion of curriculum implementation as faithful transmission of developers' intentions, and of curriculum evaluation as a systematic assessment of the fulfillment of those intentions (Ben-Peretz, 1975, 1990). According Ben-Peretz, curriculum materials are expressions of developers' intentions (in terms of learning outcomes, topics, activities, pedagogical approaches, etc.), containing curriculum or educational potential. However, curriculum materials are "richer in educational potential" than what is stated by the developers (Ben-Peretz, 1990, p. 8). Apart from what is intended by the developers, curriculum potential encompasses unintended learning outcomes (resulting from the implementation of a material) and the different possible uses of the material revealed by the teacher's analysis and interpretation. Through advancing the notion of curriculum potential, she argued for an alternative to curriculum implementation and evaluation that recognizes and encourages classroom teachers' diverse interpretations and uses of curriculum materials (Ben-Peretz, 1975, 1990).

To analyze the potential of a curriculum material, then, is to reveal the "manifold possible uses" that can be different from the intentions of the developers. This requires a teacher to interpret or analyze the "meanings" of the material. The interpretation can be aided by the use of a wide range of schemes and instruments, including those drawn from the teacher's past experiences, derived from the intentions of the developers, and based on theoretical perspectives outside the intentions of the designer. Through this, a teacher can adapt a material to his or her classroom situation, and/or come up with individual and creative ways of using the material. The teacher is thus liberated from the "tyranny of the text" (Ben-Peretz, 1990). 
Ben-Peretz's approach to curriculum interpretation, Werner (1993) observed, is guided by "practical interests related to instructional planning" and driven by the concern for the immediate classroom use of materials (p. 456). The approach does not entail the necessity of a careful interpretation of the curriculum embodied in the material in its own terms - an interpretation that takes account of the matter of content selection, organization, and transformation that has occurred as content is incorporated into the material. Overall, Ben-Peretz's discussion of curriculum potential has focused on what she called the second level of curriculum interpretation (the transformation of a curriculum material into learning experience by a classroom teacher) rather than the first level of curriculum interpretation (the transformation of scholarly content into curriculum materials by curriculum writers) (Ben-Peretz, 1990; Ben-Peretz \& Silberstein, 1982). Without carefully attending to what is entailed in development of curriculum materials (or the first level of curriculum interpretation), I will argue, one could not fully articulate what constitutes curriculum potential and what it means to analyze a curriculum material for potential. I shall now turn to Schwab's (1973) paper "The Practical 3".

\section{Joseph Schwab}

Whereas Ben-Peretz focused on the involvement of teachers in curriculum endeavor at the classroom level, Schwab concentrated on the undertaking of curriculum making prior to classroom instruction when introducing his notion of curriculum potential. In "The Practical 3" he discussed what is involved in process of translating scholarly materials into curriculum materials. This paper, together with other three "practical" papers (Schwab, 1969, 1971, 1983), made a case for the inadequacy of theoretical or university- 
based approach to curriculum making, and in so doing, revitalized and reinvented the "craft" tradition that foregrounds the immediate local context and the importance of curriculum deliberation in tackling various complex contextual factors critical to curriculum development (see Westbury, 2005; Westbury \& Osborne, 2001).

Curriculum making, according to Schwab (1973), entails translating scholarly materials into the school curriculum within a particular instructional context (a school or a school district). This process is undertaken by a curriculum deliberation group representing five bodies of experience — subject matter, the learner, the milieus, the teacher, and curriculum making. It entails taking account of four commonplaces - the subject matter, the learner, the teacher, and the milieu — on an equal basis. The deliberation process starts with having each group member discover the values, concerns, and intentions of the other members and the relevance of those values, concerns, and intentions to curriculum development. This is followed by "coalescence" of what has been discovered. Afterward, the group utilizes as an essential frame of reference what has been discovered and coalesced for translating scholarly material. Note that scholarly material also refers to scholarly content: a piece of scholarly material can be a mathematical theorem, a scientific concept or principle, a lyric poem, a historical account, a literary passage, etc..

For Schwab, scholarly contents are curricular resources "to be used in the service of the student" (p. 515). Whereas Ben-Peretz construed curriculum potential in terms of multiple possible uses of the material, Schwab conceived it in terms of curricular possibilities inherent in scholarly content for the development and growth of the student. To disclose those possibilities, he distinguished three "faces" of scholarly content, each 
of which carries its own educational meaning and significance, thus with its own "richness of curricular possibility" (p. 516). The first face is the purport conveyed by the content. The purport of a short story could be a moral dilemma, which could render opportunities for moral development. The second face concerns the originating discipline from which scholarly content derives, standing for "a coherent way of bringing a body of principles, methods and problems to bear upon some inchoate mass in order to give it order and meaning” (p. 515). Access to those principles, methods, and problems, Schwab argued, involves access to grounds for critical thinking, moral reasoning and deliberation. The third face concerns certain access disciplines that need to be brought to bear on the scholarly content in order to reveal its full complexity and sophistication. This allows the content to be opened to different types of questions, different perspectives or ways of thinking. These three faces are identified in line with his belief in inquiry teaching, and together represent a Schwabian way of conceptualizing or framing disciplinary content for curriculum potential. Such a way of conceptualizing or framing content, as will be further discussed in the ensuing sections, pertains to a theory of content that "imbues" curriculum content with educational meaning and significance-or with curriculum potential.

Therefore, ascertaining the curriculum potential inherent in a piece of scholarly content entails an analysis or unpacking of its educational meaning and significance in view of the three faces.

One figuratively turns the piece of scholarly material from side to side, viewing it in different lights. What use might it serve in the development of more critical loyalty to a community? What might it contribute to the child's resources for satisfying activity? What might it contribute to a moral or intellectual virtue held to be desirable by the planning group? To 
what convictions might it lead concerning conservation or reform of a community setting? To what maturation might it contribute? (p. 520)

This analysis, according to Schwab, is required for all pieces of scholarly content competing for place in the curriculum. The decision on inclusion of a particular piece of scholarly content into the curriculum is made with reference to its curriculum potential and in the light of the four curriculum commonplaces.

From the subject matter: It the purport of the material an important historical event or condition, for example? Is it good history, arising from well-validated facts, interpreted in a defensible way toward insights useful to our time and circumstance? From the milieu: Does it contribute toward improvement of a community? Is it likely to be acceptable to that community? If it is novel or disturbing, are there steps we can take to facilitate its acceptance? From the children: Is the good it is supposed to do more urgent or more important than the goods served by competing curricular bits? Is it appropriate to the age and experience of the children under consideration? What consequences may it have for the relations of children to parents and to other significant adults? What effect may it have on the relation of each child to himself? From the teacher: Is he or she prepared to teach it as it should be taught? Can this training be successfully centered upon? Will the teacher be in sympathy with the values embodied in the curricular bits? If not, are there prevailing values among teachers which can be used to help enlist them in the service of the embodied values? (pp. 520-521)

Hence, what is eventually selected into curriculum materials is a result of a collaborative and deliberative endeavor of translating scholarly content into curriculum content.

Therefore, curriculum materials are not merely "texts" to be read by classroom teachers for whatever instructional purposes they see fit. Underlying the material is a particular way of conceptualizing and framing scholarly content in terms of essential elements, aspects, and structures that allows content to open up educational meaning and significance. Attending to this "built-in" way of conceptualizing and framing content is necessary if teachers are to adequately interpret or unpack the material for curriculum 
potential. This requirement, which has not been stressed by Ben-Peretz, will be further discussed in the next section.

However, Schwab's conception of curriculum potential is not without limitations. His thinking was informed by a version of liberal education concerned primarily with the cultivation of intellectual powers and moral reasoning capacities of individuals through academic disciplines, enabled by a liberal curriculum that promoted conversations, discourses, and practical inquiry through a "learning community" (Reid, 1984). The heavy reliance on academic disciplines (scientific, social, humanistic) as the primary source of curriculum content might render a curriculum incapable of responding effectively to the changing economic, cultural, and educational demands of a larger society (Deng \& Luke, 2008; Tanner \& Tanner, 1995). Furthermore, the advocacy of a curriculum deliberation group within a school context implies an opposition to any form of centralized or state-based curriculum development. This is further evident in his paper "The Practical 4" in which he argued for an "institutional relocation" of curriculum making from the central or state government to individual schools or school districts (Wengener, 1986). That model of curriculum making, Eisner (1984) argued, is "utopian" because it is "incompatible with the demands now being made upon American schools"(p. 205).

\section{German Didaktik}

Unlike Schwab, scholars and educators in the German Didaktik tradition acknowledge the role of state-based or centralized curriculum making. This tradition provides a way of thinking about teaching and learning that foregrounds the importance of teachers' 
interpretation and enactment of content within a well-developed state curriculum (see Hopmann, 2007; Westbury, 2000). All German states have a well-articulated state curriculum framework, the Lehrplan, which lays out school subjects and their contents to be taught in schools. However, it does not spell out the educational meaning and significance associated contents which are to be interpreted and unpacked by teachers in their classroom situations (Hopmann, 2007). Within that curriculum framework teachers have a high level of professional autonomy to interpret the state-mandated curriculum. They are viewed as reflective professionals "working within, but not directed by" the state curriculum framework, informed by the idea of Bildung and the Didaktik way of thinking (Westbury, 2000)

Bildung encapsulates what it means to be educated in the Didaktik tradition. It comprises a set of educational aims and values centered upon the formation of mind, the unfolding of capability, and the development of sensitivity of the learner (cf. Hopmann, 2007; Humboldt, 2000). The content, characteristically defined by curriculum designers as the contents of education (Bildungsinhalt), is the result of special selection and organization of the wealth of the conceivable knowledge, experiences and wisdom for Bildung. Furthermore, the content is construed as comprising educational substance (Bildungsgehalt) — essential elements, aspects or structures - that could contribute to Bildung (Klafki, 2000). Educational substance thus constitutes the educational potential contained in the content. The content, by virtue of its educational substance, has the "formative potential" or the "possible value-laden impact" on the mind of the becoming person (Krüger, 2008). 
The notion of educational substance parallels Schwab's idea of three faces (purport, original discipline, and access disciplines), both of which are used to disclose the educational potential contained in content. Identifying what constitutes educational substance is essential to teaching for Bildung (Hopmann, 2007). This notion, together with the concept of contents of education, forms a theory of content underlying the curriculum framework. As in the Schwabian tradition, in Didaktik to analyze curriculum potential entails an analysis or unpacking of educational meaning, value, and significance of curriculum content in terms of the essential elements, aspects or faces. This analysis needs to be conducted with reference to a learner or a particular group of learners within a particular historical context (present and future), informed by a theory of content from the perspective of Bildung. While Schwab focused on the process of translating scholarly content into curriculum materials, Klafki concentrated on the classroom process of translating the content into curriculum potential and into classroom experiences. $\mathrm{He}$ formulated a five-step sets of questions that explore curriculum potential—which can be called in terms of (1) exemplary value, (2) contemporary meaning, (3) future meaning, (4) content structure, and (5) pedagogical representations (see Gudmundsdottir, Reinertsen, \& Nordtømme, 2000)

1. Exemplary value: What wider or general sense or reality does this content exemplify and open up to the learner? What basic phenomena or fundamental principle, what law, criterion, problem, method, technique, or attitude can be grasped by dealing with this content as an "example"?

2. Contemporary meaning: What significance does the content in question, or the experience, knowledge, ability, or skill, to be acquired through this topic, already 
possess in the minds of the children in my class? What significance should it have from a pedagogical point of view?

3. Future meaning: What constitutes the topic's significance for the children's future?

4. Content structure: How is the content structured (which has been placed in a specifically pedagogical perspective by questions 1,2 , and 3$)$ ?

5. Pedagogical representations: What are the special cases, phenomena, situations, experiments, persons, elements of aesthetic experience, and so forth, in terms of which the structure of the content in question can become interesting, stimulating, approachable, conceivable, or vivid for children of the stage of development of this class? (Klafki, 2000)

Questions 1 to 3 explore the essential ingredients, features and significances that constitute the educational potential of the content. ${ }^{1}$ Questions 2 and 3 necessitate an analysis or unpacking of the educational meaning and significance of those essential elements - an analysis which, from the perspective of Schwab, is crucial for disclosing the curriculum potential inherent in the content. By discerning those essential elements and elucidating their possible manifestations and significance, Didaktik analysis unlocks the "organic power" contained in the content that gives rise to fundamental experience leading to Bildung (see Krüger, 2008). Questions 4 \& 5 concern the means of actualizing the potential - in terms of content structure and pedagogical representations - which is an outgrowth of analyzing the content in terms of educational potential. It is important to note that the search for methods (i.e., the means for actualizing potential) is the final step - the "crowning" moment in instructional preparation (Klafki, 2000). 
In other words, the discussion of educational potential and its actualization presupposes a careful analysis of curriculum content for educational meaning and significance - an analysis that is guided by an educational ideal and informed by a theory of educational content that underlies curriculum material. Such an analysis is relatively unknown to the American tradition of curriculum and instruction. Unlike in the American tradition, in Didaktik teaching is not construed in terms of delivering a body of "objectified" knowledge and skills to learners (Westbury, 2000). Rather, it is viewed in terms of a "fruitful encounter" between content and the learner (Klafki, 2000). This requires the teacher to analyze and unpack content in a way that opens up its educational meaning and significance. As Hopmann (2007) puts it, the central question of Didaktik is "if and how the educative substance could be opened up for the students as intended," or more exactly, "if and how it became open in their individual meeting with the content in the given teaching process" (p. 117).

However, as in Schwab's thinking, in Didaktik the notion of curriculum potential is inextricably associated with a version of liberal education (i.e. Bildung) that centers on the cultivation of intellectual and moral capacity of individuals. The analysis of curriculum potential is largely limited to the questions of what potential the content is reckoned to have for Bildung and how this potential can be actualized. It tends to overlook social, cultural and political expectations or demands on schooling as well as the translation of those expectations/demands which carry implications for the meaning and significance of curriculum content. ${ }^{2}$ In what follows I discuss what an analysis of curriculum content for curriculum or educational potential entails by way of a curriculum making framework - a framework that allows us to, on the one hand, avoid the 
limitations inherent in Schwab's thinking and in German Didaktik tradition, and on the other, take account of some of their important insights.

\section{Three contexts of curriculum making}

According to Goodlad and associates (1979), curriculum is "made" in different places of the system: in government departments of education, in boards of education, and in schools. Broadly construed, curriculum making runs across three types of context, the institutional, the programmatic, and the classroom, each of which is characterized by a distinct kind of curriculum.

- The institutional curriculum, or the ideal or abstract curriculum, defines the connection between schooling and society, embodying a conception of what schooling should be with respect to the society and culture. It "typifies" what is desirable in social and cultural orders, what is to be valued and sought after by members of a society or nation (Doyle, 1992a, 1992b).

- The programmatic curriculum, or the analytic or technical curriculum, translates the ideal or abstract curriculum into curriculum structures, programs, school subjects or courses of study provided to schools or a system of schools (Doyle, 1992a, 1992b; Westbury, 2000). It takes the form of curriculum documents, syllabi, textbooks and the like. The process of constructing a school subject or course of study entails the selection and arrangement of content (knowledges, skills, and dispositions) and the transformation of that content for school and classroom use. It involves a "theory of content" that connects content to both 
institutional expectations and the activities of teaching and learning (Doyle, 1992b).

- The classroom curriculum refers to what is taught and learned in schools and classrooms, represented by a cluster of events jointly developed by a teacher and a group of students within a particular school or classroom (Doyle, 1992a, 1992 b). Curriculum making at this level transforms the school subject or course of study embodied in curriculum materials into "educative" experiences for students. It requires further elaboration of the content of a school subject or course of study, making it connect with the experience, interests, and the capacities of students in a particular classroom (Westbury, 2000).

These three contexts are "loosely coupled" (Westbury, 2008), each of which contributes a distinctive layer of meaning to curriculum content.

In the institutional arena, what should count as content has to do with public expectations or aims of schooling. Apart from forming or cultivating the mind and personality as typified in Bildung or liberal education, schools are expected to equip students with the requisite knowledge and skills for economic productivity. They are expected to help students cultivate the kind of awareness, disposition, and value necessary for civic participation and nation building (c.f. Fiala, 2006). Furthermore, schools are supposed to contribute to ameliorating social problems and engendering social reform (c.f. Eisner \& Vallance, 1974; McNeil, 1996). These expectations or purposes speak to the responsibilities that schooling as an institution needs to bear in contributing to the social, economic, and political well-beings of a society. They demand 
curriculum content — no matter what form it might take — to be viewed as something with social, economic, and political meaning and significance.

In the programmatic context, what constitutes curriculum content has to do with the formation of a school subject or course of study embodied in curriculum materials. The meaning and significance of content are further determined and shaped by a theory of content - a particular way of conceptualizing, selecting, organizing and transforming content for institutional, curricular, and pedagogical purposes - that underpins the formation of a school subject (Deng, 2009). In other words, curriculum materials contain not merely content but also a theory of content.

At the classroom level, the meaning and significance of content have to do with classroom enactment of a school subject. When using curriculum materials, a teacher is supposed to translate the content-more precisely, the theory of content-into instructional events and activities within a particular instructional context and toward particular educational purposes. What constitutes the content, what meaning and significance that content has, and how students can experience this meaning and significance are thus determined by the teacher's interpretation of educational purposes and the theory of content, which is ultimately shaped by his or her understanding of learners, of self, of pedagogy, and of the instructional context.

In short, the meaning and significance of content are embedded in a web of institutional, programmatic, and classroom considerations or discourses. Then, a sensible approach to analyzing educational potential embodied in content demands that we be aware of and attentive to all three realms of curriculum consideration. As an illustration, I 
now discuss what is involved in interpreting the content of liberal studies for curriculum potential.

\section{Interpreting the content of liberal studies}

The introduction of liberal studies is inextricably connected with recent curriculum reform in Hong Kong in response to the changing political and social contexts-characterized by globalization, a knowledge-economy, and an increasing close tie with mainland China. Since 2009 the government has implemented the new " $3+3+4$ ” system, according to which there are 3 years lower secondary, 3 years senior secondary, and (normally) 4 years undergraduate education. Aligned with that system is the New Senior Secondary (NSS) Curriculum, consisting of four core school subjects (Chinese, English, mathematics, and liberal studies), elective subjects (e.g., physics, chemistry, and history), and other learning experiences (moral and civic education, community service, aesthetic and physical activities).

Liberal studies thus becomes a compulsory subject for all senior secondary school students. At the institutional level, the goals of this subject are defined in terms of broadening students' knowledge base, enhancing their social awareness, cultivating positive values and attitudes, and developing critical thinking and lifelong learning capacities - qualities believed to be important for facing the challenges of the $21^{\text {st }}$ century. In view of this, curriculum content is construed as a resource for helping students develop those qualities. This is consistent with Schwab or Klafki concerning how curriculum content is viewed. Yet it is a stark contrast to conventional school 
subjects where content is construed as merely a corpus of facts, concepts and skills for transmission.

At the programmatic level, central to the formation of liberal studies is a theory of content — a special way of selecting, arranging and framing content — that can bring about curricular opportunities for developing those qualities. This theory of content is evident in the official curriculum document that lays out the curriculum framework and related instructional and assessment guidelines (cf. CDC \& HKEAA, 2007). Content is selected and organized by way of a "student-oriented approach," with the intention to "help students understand themselves, and their relations with others and the environment in which they live" (p. 4). Accordingly, three broad content areas are selected or identified, namely "Self and Personal Development," "Society and Culture," and "Science, Technology and the Environment." These three areas are further divided into six learning modules including: (1) personal development and interpersonal relationships; (2) Hong Kong today society; (3) modern China; (4) globalization; (5) public health; and (6) energy technology and the environment. Each module is framed in terms of themes, each of which embodies key concepts (laid out in the prologue) and key issues for inquiry. For each theme, the framework suggests related issues for exploration and related values and attitudes that teachers can help students develop. Table 1 below illustrates the way content is arranged and framed for the module energy technology and the environment.

Insert Table 1 here 
This way of selecting, arranging, and framing content is intended to facilitate the employment of cross-curricular and issue-based inquiry approaches to teaching and learning. The key and related issues are purported to be controversial so as to encourage students' critical thinking. They are intended to be cross-curricular or interdisciplinary, the examination of which requires drawing on differing perspectives, ways of thinking, and values from various school subjects and other learning experiences. Furthermore, the issues are supposed to arise from various contexts that are familiar to students, so they can draw upon their existing knowledge to construct new understandings or perspectives. Through selecting, arranging and framing content in this manner, curriculum designers posit educational potential for the content of liberal studies - in terms of broadening perspectives, enhancing social awareness, cultivating positive values and attitudes, and developing critical thinking.

At the classroom level teachers are supposed to develop school-or-classroom based curriculum on the basis of the curriculum framework. They are supposed to interpret and translate the content (i.e., the theory of content) embodied in the framework into instructional events and activities, with reference to the institutional goals of the subject and to students' existing knowledge and experiences within a particular instructional context. They are expected to build and expand upon what students already know, engaging them in the process of constructing their own knowledge and developing desirable attributes and abilities.

In other words, interpreting the content of liberal studies for curriculum potential requires attending to institutional, programmatic, and classroom meaning and significance. It entails an understanding of how content is organized, framed and 
transformed for educational, epistemological (or psychological), curricular, and pedagogical purposes within a particular classroom context. Four interrelated aspects entailed in interpreting the content of a particular module or topic can be identified including: inquiry framing (framing content for cross-curricular and issue-based inquiry), socio-cultural framing (framing content with reference to socio-cultural contexts), psycho-epistemological framing (framing content with reference to the curricular or knowledge context of students), and pedagogic translation (translating content into teaching and learning activities and selecting instructional resources). Each of these aspects can be characterized by a set of initial probing questions.

Inquiry framing

- What are the themes and key issues (i.e., questions for inquiry) pertaining to the module?

- What are the key concepts that underlie each of the themes? How are these concepts related to the concepts in other modules?

- What could be the key and the related issues for exploration?

Socio-cultural framing

- What significance do the related concepts, key issues and related issues have for students, the society and the world?

- How might these issues arise from various socio-cultural contexts?

- What different perspectives can be brought to bear on addressing these issues?

- What kinds of critical thinking can be encouraged? What attitudes and values are worthy of cultivation?

Psycho-epistemological framing 
- What prerequisite knowledge and skills are needed for learning the issues and concepts?

- How might the key issues and concepts connect with what students learn in other school subjects or from other learning experiences in the curriculum?

- What do students have already known and experienced in relation to these issues and concepts?

- How might their existing knowledge and experience be drawn upon for learning the issues and concepts?

\section{Pedagogic translation}

- On the basis of the above considerations, what could be teaching and learning activities (e.g., group discussion, debate, role-play, project work, and independent inquiry) that could broaden students' perspectives and provide them with opportunities for problem-solving, independent learning, and cross-curricular and critical thinking?

- What resources (e.g., the media, IT software, and the internet) could be employed for achieving the instructional purposes? What tools are most useful for assessing student learning? How could the results of assessment be used to inform instruction?

These four aspects intertwine the content with issues of teaching, learning, and assessment. Engaging with the questions pertaining to the four aspects allows teachers to consider the what, why, and how questions around the teaching of a particular module or topic. It allows teachers to interpret and reinvent the meaning and significance the content in a particular instructional setting, thus disclosing the curriculum potential embodied in content (see Deng, 2009).

\section{Discussion}

I have argued that interpreting curriculum materials for educational potential requires a careful analysis and unpacking of curriculum content for meaning and significance within 
a particular instructional context. This analysis and unpacking need to be informed by an understanding of a theory of content embodied in materials - a special way of selecting, organizing and framing content for educational, curricular and pedagogical purposes. So far, this paper has taken what is called an internalist perspective on curriculum contenta perspective that examines curriculum content in its own right, construing it as having intrinsic educational meaning and significance with respect to the learner and society (Moore, 2000). It is important to acknowledge that the "meaning" of content can also be analyzed from an externalist perspective widely employed in sociological and sociohistorical literature on school curriculum ${ }^{3}$ - a perspective that views curriculum content as a mechanism of social and cultural reproduction and a device for capitalist hegemony (Moore, 2000). This paper employs the former perspective because its primary focus is on content issues intrinsic to the development and use of curriculum materials-issues concerning how content can be selected, arranged, framed and transformed so as to render meaningful and educative experiences for learners.

As mentioned at the beginning, the need to analyze and unpack the meaning and significance of curriculum content has not received sufficient attention in the literature concerning teachers' use of curriculum materials which foregrounds the agency of a teacher. It has also been silent in Shulman and associates' model of pedagogical reasoning that foregrounds a teacher's ability to transform the content of an academic discipline for classroom teaching. To a certain degree, the preoccupation with a teacher's agency or with a teacher's transformation of disciplinary content has meant that the “curriculum" embodied in curriculum materials can be ignored or bypassed. 
Then, to argue for the need to analyze and unpack the meaning and significance of content is to call attention to the curriculum - a school subject or course of studyembodied in curriculum materials. A school subject can be seen as "a uniquely purposebuilt educational enterprise, designed with and through educational imagination towards educative ends" (Deng \& Luke, 2008, p. 83). Underpinning a school subject is a theory of content - a special way of selecting, arranging, framing and translating content for social, cultural, educational, curricular and pedagogical purposes- that requires the attention from teachers if they are to adequately interpret materials for curriculum potential (Deng, 2009). Attending to the theory of content enables a teacher to see what the content is how the content can open up meaning and significance--or curriculum potential — in view of broad educational goals or ideals, and therefore (re)create meaning and significance within a particular classroom context.

This paper holds that the school subject—rather than the academic disciplinelies at the heart of classroom teaching (see Deng [2007a] for a detailed discussion). Classroom teachers interpret and transform the content of the school subject so as to disclose and actualize its educational potential. Note that the content is viewed as the resource for achieving educational goals or ideals rather than a body of facts, concepts and principles for transmission or delivery. This contrasts sharply with the model of pedagogical reasoning that presumes the necessity of transforming the content of the academic discipline (rather than the content of the school subject) by a teacher for classroom teaching (Deng, 2007a, also 2007b). It also contrasts sharply with the notion of PCK that tends to construe teaching as a transmission or delivery of disciplinary content (see Meredith, 1995). ${ }^{4}$ The preoccupation with a teacher's transformation and 
transmission of disciplinary content has meant that a teacher's interpretation of the content of the school subject (embodied in curriculum materials) for educational meaning and significance can be overlooked (Deng, 2007a). As a result, the concept of PCK, together with the model of pedagogical reasoning, Hopmann (2007) observed, "systematically fails to reconstruct subject matter as open space for the invention of future meaning" (p. 121).

To call attention to the curriculum embodied in materials does not imply undermining the agency of a classroom teacher. Nor does it mean to undermine the role of a teacher's disciplinary knowledge and ability to transform that knowledge for classroom teaching. The teacher is a curriculum maker in the sense that he or she interprets and transforms the written curriculum into learning experiences using his or her personal practical knowledge, in consideration of curriculum commonplaces - the teacher or self, students, subject matter, and milieu (see Clandinin \& Connelly, 1992; Connelly \& Clandinin, 1988). The interpretation and transformation, of course, are enabled by the teacher's knowledge of the academic discipline and PCK. The point the article stresses is that meaningful curriculum work at the classroom level needs to be grounded not only in a teacher' personal practical knowledge, disciplinary knowledge and PCK, but also in a well-informed and responsible understanding of the curriculum embodied in materialsbroadly construed. The teacher is imaged as a responsible curriculum maker who is grappling with the most basic how, what, and why questions around curriculum content in a classroom, with respect to broad institutional goals or ideals and to the programmatic curriculum embodied in curriculum materials (Westbury, 2000). This image of teaching recognizes that teachers work within a conception of the public good, and within an 
organizational framework of public education (Westbury, 1994). They are the "intermediaries" between the institutional/programmatic curriculum and the classroom curriculum (Reid, 2006).

The process of constructing curriculum materials involves "constructing a set of often-technical arguments that rationalize the selection and arrangement" of content and the "transformation, through simplification, elementarization, and representation," of that content into forms suitable for classroom use (Doyle, 2010). Curriculum developers have to interpret or theorize content with respect to curriculum aims or ideals and classroom practice. Through interpreting or theorizing content, curriculum developers "posit" educational potential for content (Doyle, 2010, also 2008). Yet this important curriculum work has been under-investigated and under-theorized in the field of curriculum studies or theorizing. This is an urgent need to revitalize and renew the commitment of curriculum studies to investigate and theorize this complex task of curriculum making in today's era of globalization. The current international discourse on curriculum development has been heavily dominated by a technical language of national standards and outcomes, where "formalized curriculum-making is ignored or even contested in favor of assessment and accountability" (Karseth \& Sivesind, 2010, p. 104). Such a discourse is deceptively dangerous for it diverts our attention from the heart of teaching and learning - the curriculum (and its making). It must to be challenged by foundational curriculum scholarship that foregrounds the importance of and speaks to the complexity of curriculum making - be it at the institutional, programmatic or classroom/school level. What should be the aims and outcomes of schooling for the $21^{\text {st }}$ century? How might these aims and outcomes be translated into programs, courses of study, school subjects or 
areas of learning experiences? How should content be selected, arranged and framed so as to "imbue" these programs, subjects or areas with curriculum potential in the light of these aims and outcomes? These are important and challenging questions about curriculum making that today curriculum scholars much provide answers.

So far the discussion of curriculum potential has primarily focused on the potential contribution of curriculum content to the development and growth of learners. Curriculum potential can refer to the contributions of other curriculum constituent elements as well—e.g., pedagogy and assessment—since curriculum materials contain not only content specification but also recommendations of instructional methods and activities, and of assessment criteria and modes. Furthermore, the notion can be extended to the potential contribution of curriculum materials to classroom teachers as well. As Ball \& Cohen (1996) argued, curriculum materials can be an important resource for teacher learning — in addition to student learning. Properly developed, curriculum materials can help teachers develop a better understanding of the content and of students, expand their curricular resources and pedagogical repertoires, and support their pedagogical decision making (Ball \& Cohen, 1996; Davis \& Krajcik, 2005; Remillard, 2000). Furthermore, syllabus documents, when properly designed and aligned with certain external conditions, have the potential to enhance teacher professional practice and to improve outcomes for all students (Luke et al., 2008). I hope that there will be more inquiry — both conceptual and empirical—into the richness and complexity of curriculum potential. 


\section{Acknowledgement}

An earlier version of this article was presented in the first international conference on the "practical"-- The Practical: An East-West Curriculum Dialogue, Capital Normal University, Beijing, China, June 12-14, 2009. I want to express my sincere gratitude to Miriam Ben-Peretz for her support and encouragement. I am also very thankful for the meaningful inputs of Ian Westbury, Michael Connelly and Cheryl Craig and particularly for the thoughtful comments of the journal editors and four anonymous reviewers.

\section{References}

Apple, M. W. (1979). Ideology and Curriculum. Boston, MA: Routledge \& Kegan Paul.

Bernstein, B. (1971). On the classification and framing of educational knowledge. In M. F. D. Young (ed.), Knowledge and Control: New Directions for the Sociology of Education (pp. 47-69). London: Collier-Macmillan.

Ball, D., \& Cohen, D. K. (1996). Reform by the book: What is - or might be - the role of curriculum materials in teacher learning and instructional reform? Educational Researcher, 25, 6-8, 14.

Ben-Peretz, M. (1975). The concept of curriculum potential. Curriculum Theory Network 5(2), 151-159.

Ben-Peretz, M. (1990). The teacher-curriculum encounter: Freeing teachers from the tyranny of texts. Albany: State University Press.

Ben-Peretz, M., \& Silberstein, M. (1982). Curriculum interpretation and its place in teacher education programs. Interchange, 13(4), 47-55.

Brown, M., \& Edelson, D. C. (2003). Teaching as design: Can we better understand the ways in which teachers use materials so we can better design materials to support their changes in practice? Evanston, IL: The Center for Learning Technologies in Urban Schools).Retrieved February 3, 2010, from http://www.inquirium.net/people/matt/teaching_as_design-Final.pdf.

Clandinin, D. J., \& Connelly, F. M. (1992). Teacher as curriculum maker. In P. W. Jackson (Ed.), Handbook of research in curriculum (pp. 402-435). New York: Macmillan.

Cohen, D. K., \& Ball, B. L. (1990a). Policy and practice: An overview. Educational 
Evaluation and Policy Analysis, 12(3), 233-239.

Cohen, D. K., \& Ball, B. L. (1990b). Policy and practice: A commentary. Educational Evaluation and Policy Analysis, 12(3), 331-338.

Cohen, D. K., Raudenbush, S. W., \& Ball, D. L. (2003) Resources, instruction, and research. Educational Evaluation and Policy Analysis, 25(2), 119--142.

Collopy, R. (2003). Curriculum materials as a professional development tool: How a mathematics textbook affected two teachers' learning. Elementary School Journal, 103(3), 287.

Connelly, F. M., \& Clandinin, D. J. (1988). Teachers as curriculum planners: Narratives of experience. New York: Teachers College Press.

Curriculum Development Council and Hong Kong Examination and Assessment Authority (CDC \& HKEAA) (2007). Liberal Studies: Curriculum and Assessment Guide (Secondary 4-6). Hong Kong: Education Bureau. Retrieved 3 February, 2010, from http://www.edb.gov.hk/FileManager/EN/Content_5999/ls_final_e 070508.pdf.

Davis, E. A. (2006). Preservice elementary teachers' critique of instructional materials for science. Science Education, 90(2), 348-375.

Deng, Z. (2007a). Knowing the subject matter of a secondary school science subject. Journal of Curriculum Studies, 39 (5), 503-535.

Deng, Z. (2007b). Transforming the subject matter: Examining the intellectual roots of pedagogical content knowledge. Curriculum Inquiry, 37 (3), 279-295.

Deng, Z (2009). The formation of a school subject and the nature of curriculum content: an analysis of liberal studies in Hong Kong. Journal of Curriculum Studies, 41 (5), 585604.

Deng, Z., \& Luke, A. (2008). Subject matter: Defining and theorizing school subjects. In F.M. Connelly, M. F. He, \& J. Phillion (Eds.), The Sage Handbook of Curriculum and Instruction (pp. 66-87). Thousand Oaks, CA: Sage.

Doyle, W. (1992a). Curriculum and pedagogy. In P. W. Jackson (Ed.), Handbook of research on curriculum (pp. 486-516). New York: Macmillan.

Doyle, W. (1992b). Constructing curriculum in the classroom. In F. K. Oser, A. Dick, J. Patry (Eds.), Effective and responsible teaching: The new syntheses (pp. 66-79). San Francisco: Jossey-Bass Publishers.

Doyle, W. (2008). Competence as a blurred category in curriculum theory. Paper presented at conference, "Research on vocational education and training for international 
comparison and as international comparison," Georg-August-Universität, Göttingen, Germany.

Doyle, W. (2010). Teaching as a curriculum process. Paper presented at the meeting of the American Educational Research Association, Denver.

Eisner, E.W., \& Vallance, E. (Eds.). (1974). Conflicting conceptions of the curriculum. Series on Contemporary Educational Issues. Berkeley, CA: McCutchan.

Eisner, E. (1984). No easy answers: Joseph Schwab's contributions to curriculum. Curriculum Inquiry, 14(2), 201-210.

Fiala, R. (2006). Educational ideology and the school curriculum. In A. Benavot \& C. Braslavsky (Eds.), School knowledge in comparative and historical perspective: Changing curricula in primary and secondary education. (pp. 15--34). CERC Studies in Comparative Education, No 19. Hong Kong: University of Hong Kong, Comparative Education Research Centre.

Freeman, D. J., \& Porter, A. C. (1989). Do textbooks dictate the content of mathematics instruction in elementary schools? American Educational Research Journal, 26(3), 403421.

Goodson, I. F., \& Marsh, C. J. (1996). Studying School Subjects. London: Falmer.

Goodson, I. F., Anstead, C. J., \& Mangan, J. M. (1998). Subject Knowledge: Readings for the Study of School Subjects. London: Falmer.

Goodlad, J. I., \& Associates. (1979). Curriculum inquiry: The study of curriculum practice. New York: McGraw-Hill.

Gudmundsdottir, S., Reinertsen, A., \& Nordtømme, N. P. (2000). Klafki’s Didaktik analysis as a conceptual framework for research on teaching. In I. Westbury, S. Hopmann, \& K. Riquarts (Eds.), Teaching as a reflective practice: The German Didaktik tradition_(pp. 319-334). Mahwah, NJ: Lawrence Erlbaum Associates.

Hopmann, S. (2007). Restrained Teaching: The common cores of Didaktik. European Educational Research Journal, 6(2), 109-124.

Humboldt, W. V. (2000). Theory of Bildung. In I. Westbury, S. Hopmann, \& K. Riquarts (Eds.), Teaching as a reflective practice: The German Didaktik tradition (pp. 57-61). Mahwah, NJ: Lawrence Erlbaum Associates.

Karseth, B., \& Sivesind, K. (2010). Conceptualizing curriculum knowledge within and beyond national context. European Journal of Education, 45 (1), 103-104. 
Klafki, W. (1998). Characteristics of critical constructive Didaktik. In B. B. Gundem \& S. Hopmann (Eds.), Didaktik and/or curriculum: An international dialogue (pp. 3-7-330). New York: Peter Lang.

Klafki, W. (2000). Didaktik analysis as the core of preparation. In I. Westbury, S. Hopmann, \& K. Riquarts (Eds.), Teaching as a reflective practice: The German Didaktik tradition (pp. 139-159). Mahwah, NJ: Lawrence Erlbaum Associates.

Krüger, R. A. (2008). The significance of the concepts "elemental" and "fundamental" in didactic theory and practice. Journal of Curriculum Studies, 40(2), 215-250.

Luke, A., Weir, K., Woods, A. and Moroney, M. (Eds). (2008). Development of a set of principles to guide a $P-12$ syllabus framework. Brisbane: Queensland Studies Authority. Retrieved August 12, 2010, from http://www.qsa.qld.edu.au/downloads/publications/qsa_p-12_principles_dev_ppr.pdf.

McNeil, J. (1996). Curriculum: A comprehensive introduction (5th ed.). New York: HarperCollins.

Meredith, A. (1995). Terry's Learning: some limitations of Shulman's pedagogical content knowledge. Cambridge Journal of Education, 25(2), 175 - 187

Moore, R. (2000). For knowledge: tradition, progressivism and progress in educationreconstructing the curriculum debate. Cambridge Journal of Education, 30(1), 17-36.

Nicol, C. and Crespo, S. (2006). Learning to teach with mathematics textbooks: how preservice teachers interpret and use curriculum materials. Educational Studies in Mathematics, 62 (3), 331-355.

Popkewitz, T. S. (1987). The Formation of School Subjects: The Struggle for Creating an American Institution. London: Falmer.

Remillard, J. T. (1999). Curriculum materials in mathematics education reform: A framework for examining teachers' curriculum development. Curriculum Inquiry, 29(3), 315-342.

Remillard, J. T. (2000). Can curriculum materials support teachers' learning? Two fourth-grade teachers' use of a new mathematics text. Elementary School Journal, $100(4), 331-350$.

Remillard, J. T. (2005). Examining key concepts in research on teachers' use of mathematics curricula. Review of Educational Research, 75(2), 211- 246.

Reid, W. A. (1984). Curriculum, community, and liberal Education: A response to the Practical 4. Curriculum Inquiry, 14(1), 103-111. 
Reid, W. A. (2006). The pursuit of curriculum: schooling and the public interest. Greenwich, CT: Information Publishing

Schneider, R. M., Krajcik, J. and Blumenfeld, P. (2005). Enacting reform-based science materials: the range of teacher enactments in reform classrooms. Journal of Research in Science Teaching, 42(3), 283-312.

Schwab, J. J. (1969). The practical: A language for curriculum. School Review, 78, 1-23.

Schwab, J. J. (1971). The practical: Arts of eclectic. School Review, 79, 493-542

Schwab, J. J. (1973). The practical 3: Translation into curriculum. School Review, 81, 501-522.

Schwab, J. J. (1983). The practical 4: Something for curriculum professors to do. Curriculum Inquiry, 13(3), 239-265.

Sherin, M. G., \& Drake, C. (2009). Curriculum strategy framework: Investigating patterns in teachers' use of a reform-based mathematics curriculum. Journal of Curriculum Studies, 41(4), 467-500

Shkedi, A. (1998). Can the curriculum guide both emancipate and educate teachers? Curriculum Inquiry, 28(2), 209-229.

Shkedi, A. (2009). From curriculum guide to classroom practice: teachers' narratives of curriculum application. Journal of Curriculum Studies, 41(6), 833 - 854

Shulman, L. S. (1986). Those who understand: Knowledge growth in teaching. Educational Researcher, 15(2), 4-14.

Shulman, L. S. (1987). Knowledge and teaching: Foundations of the new reform. Harvard Educational Review, 57(1), 1-22.

Tanner, D., \& Tanner, L. N. (1995). Curriculum development: Theory into practice (3 ${ }^{\text {rd }}$ ed.). Englewood Cliffs, NJ: Merrill.

Young, M. F. D. (1971). Knowledge and Control: New Directions for the Sociology of Education. London: Collier-Macmillan.

Wengener, C. (1986). Being practical with Schwab. Curriculum Inquiry, 16(2), 215-232.

Werner, W. (1993). Interpreting curricular potential. Curriculum Inquiry, 23(4), 455-461.

Westbury, I (1994). Deliberation and the improvement of schooling. In J. T. Dillon (Ed.), Deliberation in education and society (pp. 35-65). Norwood, NJ: Ablex Publishing Corporation 
Westbury, I. (2000). Teaching as a reflective practice: What might didaktik teach curriculum. In I. Westbury, S. Hopmann, \& K. Riquarts (Eds.), Teaching as a reflective practice: The German Didaktik tradition (pp. 15-39). Mahwah, NJ: Lawrence Erlbaum Associates.

Westbury, I. (2005). Reconsidering Schwab's "practicals": A response to Peter Hlebowitsh's "Generational ideas in curriculum: A historical triangulation." Curriculum Inquiry, 35(1), 89-101.

Westbury, I. (2008). The making of formal curricula: Why do states make curricula, and how? In Connelly, F. M., He, M. F., and Phillion, J. (eds.), Handbook of Curriculum and Instruction (pp. 45-65). Thousand Oaks, CA: Sage.

Westbury, I., \& Osborne, M. D. (2001). Joseph. J. Schwab 1910-1988. In J. A. Palmer (Ed.), Fifty modern thinkers on education: from Piaget to the present (pp. 73-78). New York \& London: Routledge.

Wilson, S. M., Shulman, L. S., \& Richert, A. E. (1987). "150 different ways" of knowing: Representations of knowledge in teaching. In J. Calderhead (Ed.), Exploring teachers' thinking (pp. 104-124). London: Cassell. 
Table 1. Content Selection, Arrangement, and Framing in the Module "Energy Technology and the Environment"

\begin{tabular}{|c|c|}
\hline Prologue & $\begin{array}{l}\text { Energy technology enhances the efficiency of energy utilisation, } \\
\text { and this inevitably invites us to use more energy. Our } \\
\text { dependency on energy affects scientific and technological } \\
\text { development. Such interaction also has an impact on social } \\
\text { development: the use of energy affects the environment and the } \\
\text { changes in our environment alter our views on the use of energy. } \\
\text { Therefore, the use of energy, social development, and scientific } \\
\text { and technological development are mutually interdependent. } \\
\text { They pose a challenge to the balance of the ecosystem and our } \\
\text { living environment. Sustainability has become a crucial goal in } \\
\text { dealing with environmental development. } \\
\text { In this module, students will be asked to evaluate issues } \\
\text { concerning energy technology and the environment from a } \\
\text { variety of perspectives, informed by scientific, technological, } \\
\text { environmental, historical, social and cultural data. They will } \\
\text { develop an awareness of the complex interrelationships and } \\
\text { interdependencies involved. It is hoped that recognition of the } \\
\text { impact of science and technology on our lives will lead to } \\
\text { empathy for living things, a love of the environment, an } \\
\text { understanding of the need for sustainable development for our } \\
\text { society, country and the world, and to nurture responsible global } \\
\text { citizenship. }\end{array}$ \\
\hline \multicolumn{2}{|c|}{ Theme 1: The influences of energy technology } \\
\hline Key issue & $\begin{array}{l}\text { How do energy technology and environmental problems relate } \\
\text { to each other? }\end{array}$ \\
\hline Related issues & $\begin{array}{l}\text { How does the development of energy technology affect the } \\
\text { exploitation and use of energy? To what extent does the } \\
\text { development of energy technology create or solve } \\
\text { environmental problems? What are the implications of } \\
\text { environmental change on the development of energy } \\
\text { technology? How do energy problems affect international } \\
\text { relationships, and the development of countries and societies? }\end{array}$ \\
\hline $\begin{array}{l}\text { Related values and } \\
\text { titudes }\end{array}$ & Betterment of humankind; respect for evidence; interdependence \\
\hline \multicolumn{2}{|c|}{ heme 2: The environment and sustainable development } \\
\hline ey issue & $\begin{array}{l}\text { Why has sustainable development become an important } \\
\text { contemporary issue? What is the relationship between its } \\
\text { occurrence and the development of science and technology? }\end{array}$ \\
\hline Related issues & $\begin{array}{l}\text { How do science and technology match with sustainable } \\
\text { development? What are the constraints? How do the living }\end{array}$ \\
\hline
\end{tabular}




\begin{tabular}{|l|l|}
\hline & $\begin{array}{l}\text { styles of people and social development affect the environment } \\
\text { and the use of energy? What responses could be made by the } \\
\text { public, different sectors, and governments regarding the future } \\
\text { of sustainable development? }\end{array}$ \\
\hline $\begin{array}{l}\text { Related values and } \\
\text { Attitudes }\end{array}$ & $\begin{array}{l}\text { Responsibility; caring for the living and non-living } \\
\text { environments; betterment of humankind; sustainability; } \\
\text { simplicity }\end{array}$ \\
\hline
\end{tabular}

\footnotetext{
${ }^{1}$ Question 1 can be seen as a question concerning Schwab's three faces of content (purport, originating discipline and access disciplines) discussed earlier--if "fundamental principle," "law," "criterion," "method," "technique," or "attitude" can be derived from multiple disciplines that can be brought to bear on the content.

${ }^{2}$ I need to point out that Klafki, informed by critical social theory, has developed what is called criticalconstructive Didaktik, which is a revision and extension of the earlier version of Didaktik. To a certain extent, critical-constructive Didaktik takes into account social, cultural and political expectations on schooling, with an emphasis on the development of self-determination (autonomy) co-determination (participation) and solidarity (see Klafki, 1998). However, it has not fully addressed how those demands or expectations are translated into curriculum content.

3 See, e.g., Apple (1979), Bernstein (1971), Young (1971), Goodson and Marsh (1996), Goodson et al. (1998), and Popkewitz (1987).

${ }^{4}$ The transmissive stance of PCK is also evident in its definition:

for the most regularly taught topics in one's subject area, the most useful forms of representation of those ideas, the most powerful analogies, illustrations, examples, explanations, and demonstrations - in a word, the ways of representing and formulating the subject that make it comprehensible to others... [It] also includes an understanding of what makes the learning of specific topics easy or difficult: the conceptions and preconceptions that students of different ages and backgrounds bring with them to the learning of those most frequently taught topics and lessons. (Shulman, 1986, pp. 9-10).
} 